https://helda.helsinki.fi

\title{
Recovering from the pandemic
}

\section{Saarinen, Risto}

2021

Saarinen , R 2021 , ' Recovering from the pandemic ' , Dialog , pp. 343-344 . https://doi.org/10.1111/dial.12700

http://hdl.handle.net/10138/339650

https://doi.org/10.1111/dial.12700

acceptedVersion

Downloaded from Helda, University of Helsinki institutional repository.

This is an electronic reprint of the original article.

This reprint may differ from the original in pagination and typographic detail.

Please cite the original version. 
Recovering from the Pandemic

Risto Saarinen

From March 2020 until September 2021, all my regular teaching at the University of Helsinki has taken place online. I have attempted to supervise doctoral students in regular live meetings, but even this has taken place in somewhat clandestine fashion. I am writing this in September 2021 when the new academic year is starting and both teachers and students need to decide how to continue their life at the university.

Finland has done better than most countries in the pandemic. In our 5.2 million population, we have had only 1000 covid deaths. The national economy has not suffered great losses. As schools and universities were already accustomed to digital learning environments before the pandemic, the transition to Zoom and Teams interaction has not provided technological hurdles.

On the other hand, we are now only starting to realize how the fabric of civil society has suffered. Finns have never been very good in face-to-face communication, and the time of isolation has eroded our social skills in slow and hidden ways. In our Lutheran majority church, for instance, Sunday services were smoothly provided online, with the option of receiving the Lord's Supper in small groups after the service. While this practice worked technically well, the number of people who actually participated remained small.

More importantly, it now seems that the Finns do not find their way back to live Sunday services when restrictions are being lifted. The same phenomenon can be seen in sports events, concerts, and the theatre. People say how great it is to go to an actual ice hockey game or to the church after the long break, but the actual numbers of participants remain much lower than before the pandemic. We need a longer time to recognize our social needs and retrain our social participation skills.

As the University of Helsinki and the Lutheran Church of Finland are funded by the taxpayers, academic teachers and pastors have had no fear of losing their jobs. Many of us lived quite comfortable life during the pandemic. I was able to undertake some longer writing projects and could also practice jogging and hiking much better than before.

The university students, however, have had a completely different experience. Our student life is shaped by various annual events and feasts which normally include rich social interaction and an obligation to get to know new people. Especially for introvert students (and we have lots of those in Finland), the organized social events in the academia are the channel to the professional networks that are so important for their later career.

All these were cancelled in the pandemic. In addition, the students lost the summer jobs that normally introduce them to the church, the media or some other branch of their future expertise. As all teaching has taken place online, very many students have stayed in their childhood homes without even visiting Helsinki. Now there is a demand to continue online teaching, as so many students live in their former surroundings. This phenomenon seems to be global and it is intimately connected with the profound transformation of work life in general.

While the academia needs to participate in this greater transformation, we also need to ask what the university education requires and what is has to offer to the students. A German colleague and a dean of a theology faculty recently told me what happened to the live interaction in his campus during the pandemic. In science faculties, much of the laboratory 
work continued and thus the students there learned real-life skills. In humanities and theology, however, professors and students stayed at home and interacted only online.

Such isolation at home was often seen as a very moral choice, as nobody was harming another person epidemiologically. My colleague nevertheless considered that an exaggerated isolation could also be a way to harm others and even oneself. He said that the colleagues in science were quite creative in finding ways to collaborate and work together in the time of crisis. This creativity was also transmitted to the students in their real-life encounter.

In contemporary university, the life of a hermit is no longer the foundation of creativity in research and teaching. Introvert people in particular need social structures and organized activities to support their private reflection. As corporeal beings we need bodily encounter to develop the skills that relate to the external world. A human face does not merely exist in the Facebook or Zoom. As three-dimensional face, it is related to the body that sustains it as well as to many other bodies, reflecting this co-existence in its expressions and gestures. 